\title{
Erratum to: Analyzing Multivariate Cross-Sectional Poisson Count Using a Quasi-Likelihood Approach: The Case of Trivariate Poisson
}

Naushad Mamode Khan, Yuvraj Sunecher and Vandna Jowaheer

Erratum to:

G.A. Anastassiou and O. Duman (eds.), Intelligent

Mathematics II:Applied Mathematics and Approximation Theory, Advances in Intelligent Systems and Computing 441, DOI 10.1007/978-3-319-30322-2_27

The book was inadvertently published without including a change in one of the equations in page number 410, the variables $h(y 1, y 2, y 3)$ should be written as $-\mathrm{h}(\mathrm{y} 1, \mathrm{y} 2, \mathrm{y} 3)$. The erratum book and the chapter have been updated.

The updated original online version for this chapter can be found at 10.1007/978-3-319-30322-2_27

N. Mamode Khan · V. Jowaheer

University of Mauritius, Le Reduit, Moka, Mauritius

e-mail: n.mamodekhan@uom.ac.mu

V. Jowaheer

e-mail: vandnaj@uom.ac.mu

Y. Sunecher $(\bowtie)$

University of Technology, La Tour Koenig, Port Louis, Mauritius

e-mail: yuvisun@yahoo.com 